\title{
CONCEPT OF INDIVIDUAL'S CONSTITUTIONAL FREEDOM TO CONDUCT BUSINESS IN UKRAINE
}

\author{
Serhii Penkov', Maryna Voloshyna²
}

\begin{abstract}
The article analyzes the individual's constitutional freedom to conduct business. The subject of the study is the concept, content and features of the person's constitutional freedom to conduct business in Ukraine. The article's objective is after analyzing the current legislation of Ukraine and generalizations of practice of its realization to determine essence, content and features of constitutional ensuring of a regime of legality of business activity in Ukraine. The authors have used philosophical, general scientific and special methods. The dialectical method has been used to make a comprehensive analysis of the constitutional ensuring of the regime of legality of entrepreneurial activity in Ukraine and its functional purpose in present conditions. The use of methods of analysis, synthesis, systemic and structural-functional methods has allowed to study the main components of the constitutional ensuring of the regime of legality of entrepreneurial activity in Ukraine, to analyze the legal category of "individual freedom to conduct business". The use of structuralfunctional method has promoted a comprehensive research of legal relations arising in the implementation of the right to doing business. The comparative-legal method has been used in the theoretical substantiation of various aspects of the constitutional ensuring of the regime of legality of entrepreneurial activity in Ukraine. The author's definition of the individual constitutional freedom to conduct business has been proposed. The issue of peculiarities of economic management of an individual as a business entity has been considered. The legal status of an individual has been compared with the legal status of an individual entrepreneur. There is the list of individual entrepreneurs' duties. The list of restrictions on the possibility of doing certain activities by individual entrepreneurs has been given. The procedure for state registration of an individual entrepreneur has been considered. The essence and main tools of mechanisms of state regulation of business activity in Ukraine has been determined. The problem of regulatory mechanisms has been highlighted. The main functions, tools and methods that guide the state in regulating entrepreneurship have been formed. The role of the government in the regulation of the economy and the functioning of business entities has been revealed. The international experience of government regulation of entrepreneurship has been described. Statistics have been given and country-specific examples have been generated. Ways to overcome problems of stimulating small and medium businesses have been identified. Based on the analysis, generalization and systematization of scientific sources, the weaknesses of the mechanisms of government regulation of entrepreneurship in Ukraine have been highlighted. The authors have formulated conclusions and they have offered directions of improvement of government regulation for the purpose of perfecting and development of business in Ukraine. There is the analysis of current state of constitutional means of government support of entrepreneurship in Ukraine; there is the description of existing accounting regimes concerning the official registration of individuals and legal entities as business actors, as well as the regulation of normative legal requirements for conducting business in Ukraine There is the authors' vision of the content of the concept of "legality of business activities in Ukraine" regarding present tendencies of development of relations in the area of entrepreneurship and objective necessity of their regulation by constitutional means. The authors' conclusion is that the individual constitutional freedom to conduct business is a constitutionally enshrined, not prohibited, and detailed by the laws of Ukraine economic opportunity for independent, proactive, systematic activities at their own risk to exercise the right to manufacture products, perform works, provide services, trading for profit, and its features are: enshrining it in the Constitution and laws of Ukraine; no restriction or
\end{abstract}

\footnotetext{
Corresponding author:

${ }^{1}$ Dniprovskii University of the Humanities, Ukraine.

E-mail: Psv93003Vp@gmail.com

ORCID: https://orcid.org/0000-0003-4044-5824

${ }^{2}$ Dnipropetrovsk State University of Internal Affairs, Ukraine.

E-mail: Voloshka@gmail.com

ORCID: https://orcid.org/0000-0001-9416-6885
} 
prohibition of human opportunities for entrepreneurial activity; independence, initiative, regularity, riskiness of activity; manufacturing products, performing works, providing services, trade; profit.

Key words: guarantees of constitutional freedom, government regulation of entrepreneurship, constitutional freedom, entrepreneurship, business activity, legal status, offenses in the entrepreneurship, combatting offenses, freedom of entrepreneurship, entrepreneur.

JEL Classification: G28, L26, K22

\section{Introduction}

The individual's constitutional right and constitutional freedom to conduct business are closely related but not identical. The right to entrepreneurial activity, which is not prohibited by law, belongs to every person. The prohibition of certain types of entrepreneurial activity by the current laws and the restriction of entrepreneurial activity for certain categories of individuals testify to their theoretical significance and the need to solve important practical tasks related to the exercise of constitutional freedom by a person.

One of the most common business entities is an individual as a business actor. The problematic issue is the delimitation of the individual's legal status engaged in economic or other activities in the field of economy to its legal status as an entrepreneur and its legal status as an individual. Another problem is that today there is no special regulation that would establish the legal status of a citizen-entrepreneur.

The problem of the individual's constitutional right and freedom to entrepreneurial activity has been studied by several scholars, namely by constitutionalists and economists. Among them are the works by E. A. Andriukhin, T. V. Blaschuk, K. H. Boberska, L. S. Yelizarova, D. V. Zadykhailo, A. V. Kovach, O. O. Kolomiiets, T. M. Kravtsova, L. O. Nikitenko, N. O. Saniakhmetova, S. V. Riznyk, V. S. Shcherbyna, A. V. Shchuruk etc. Despite a large number of publications, we should note that the study and research of citizen participation in the economic and legal area has not been carried out enough. A number of important theoretical and practical problems remain unresolved. One of the problems is the lack of a single legislative act that would establish the specifics of the activities of an individual entrepreneur and the objective prohibitions and restrictions on doing business.

At the same time, the role of the state is significantly increasing in present society. This is manifested in various areas of activity, in particular in the development of a system of normative acts aimed at regulating the market, business, customs rules, prices, wages, and social security. State regulation of entrepreneurship is the influence of the government on the activities of business entities, the need for which is due to economic policy goals aimed at achieving sustainable development of the country and its regions, ensuring constant growth of indicators describing the welfare and quality of life of the country's population. The term "mechanism" is used in engineering where it means a device that transmits or converts motion, and the meaning of this term is associated with the internal structure of the machine. This word is used as a definition of the internal structure, the system of something; in addition, it can be used to describe the set of states and processes that make up a particular phenomenon.

Problems of improving the mechanism of state regulation of entrepreneurial activity in the context of intensification of integration processes of the country are priority tasks and require comprehensive research. There is a need to single out and generalize the terminology of "public administration" in the part concerning the concepts of regulation and state regulation of entrepreneurial activity. Separation of theoretical and methodological and practical principles of formation and development of mechanisms of state regulation of entrepreneurial activity is an important scientific and practical task that should be carried out by creating multifaceted regulatory mechanisms, adapting them to the external environment of enterprises.

\section{Components of the individual's constitutional freedom to conduct business in Ukraine}

The current Ukrainian legislation does not contain a definition of "business entity - citizen". Also in this legislation there is no single terminological approach to the definition of this category of business entities, namely the concepts are used: "citizen as a business entity", "entrepreneur with no legal entity", "citizenentrepreneur", "individual entrepreneur". We should note that the use of several terms for one concept distorts the legislator's will, makes difficulties in the application of law and negatively affects the parties' rights and interests. In this regard, the introduction of terminological uniformity in the designation of the individual as a business entity and the use of the term "business entity - citizen" has been justified, because this term is the most correct to denote the relationship between the individual and the state (Vinnyk, 2017).

An individual entrepreneur is a relatively new actor of economic law, as entrepreneurial activity in the planned distribution economy was prohibited and its legalization in Ukraine took place according to the Law of Ukraine "On Entrepreneurship" (1991), which has expired due to the entry into force of the Commercial Code of 
Ukraine. A citizen is recognized as a business entity if he/she carries out business activities subject to state registration as an entrepreneur without the status of a legal entity. A citizen-entrepreneur is liable for his/her obligations with all his/her property, which according to the law may be levied (Article 128 of the Commercial Code of Ukraine, 2003). Determinant for obtaining the status of an entrepreneur, including in the field of agriculture, is the state registration of the individual by making appropriate entries in the Unified State Register according to the Law of Ukraine "On State Registration of Legal Entities, Individual Entrepreneurs and Public Associations". According to Art. 18 of the law for the state registration, an individual entrepreneur submits the following documents:

- application for state registration of individual entrepreneurs;

- application for the choice of a simplified taxation system by an individual and/or registration application for voluntary registration as a value added tax payer in the form approved by the central executive body that ensures the formation of national tax and customs policy (at the request of the applicant);

- notarized written consent of parents (adoptive parents), or guardian, or guardianship authority for an individual who has reached sixteen years of age and wishes to engage in entrepreneurial activity, but does not have full civil capacity;

- agreement (declaration) on the establishment of a family farm - in the case of state registration of an individual who independently or with family members creates a family farm according to the Law of Ukraine "On Farming".

The procedure for state registration of an individual entrepreneur includes, in particular: verification of the completeness of documents submitted to the state registrar and the completeness of the information specified in the registration card; verification of documents submitted to the state registrar for the absence of grounds for refusal to conduct state registration; entering information about an individual entrepreneur in the Unified State Register; registration and issuance of an extract from the Unified State Register. According to Art. 26 of this law, consideration of documents submitted for state registration and other registration actions is carried out within 24 hours after receipt of documents submitted for state registration and other registration actions ("On Farming", 2003).

The legal status of an individual entrepreneur is characterized by the presence of the following elements: state registration as a business entity, registration in the state fiscal service and the Pension Fund of Ukraine as a taxpayer and a single contribution to compulsory state social insurance, respectively, making a seal (if necessary), opening a current account in a banking institution (if necessary), obtaining a license (in the case of licensed activities).
According to the subject of activity, an individual may carry out: productive entrepreneurial activity, i.e. activity in the process of which certain items are manufactured; non-productive entrepreneurial activity, within which there are: activities for the fulfillment of works, granting services (repairing work, providing information services, transportation); trade activities; other non-productive activities, in particular, activities in the financial market.

The citizen-entrepreneur carries out the activity on the principles of freedom of business and according to the principles provided in Art. 44 of the Civil Code of Ukraine. In this case, the business is understood as an independent, proactive, systematic, at their own risk, not prohibited by law activities for the manufacturing of goods, exercising works, providing services and doing trade for profit. Entrepreneurial activity can be exercised by Ukrainian citizens, citizens of other states, stateless persons, but it is limited to deputies, officials of public authorities and local self-governments, servicemen, prosecutors, employees of court, state security, etc. The citizen-entrepreneur is obliged to:

- in cases and in the manner prescribed by law to obtain a license to carry out certain types of economic activity; - to notify the state registration authorities about the change of his/her address specified in the registration documents, subject of activity, other essential conditions of his/her business activity, which are be in the registration documents;

- to observe rights and legitimate interests of consumers, to ensure the proper quality of goods (works, services) manufactured by them, to comply with the rules of mandatory certification of products established by law;

- to prevent unfair competition, other violations of antitrust and competition law;

- to keep records of their business activities results according to the legislation requirements;

- timely provide the revenues and fees bodies with a declaration of property and income (tax return), other necessary information for the calculation of taxes and other mandatory payments; pay taxes and other mandatory payments in the manner and to the extent prescribed by law (para. 6 Art. 128 of the Commercial Code of Ukraine).

The Constitution of Ukraine states the right to doing business that is not prohibited by law (Constitution of Ukraine, 1996), which is quite doubtful: entrepreneurial activity cannot be prohibited, as such activity is socially useful in a market society, and the government can only impose restrictions on implementation of its individual species or certain entities. Due to the fact that in Ukraine there is no single legislative act that would impose objective prohibitions on doing business, negative phenomena in the field of entrepreneurship often occur. The legislation contains restrictions on the ability of private entrepreneurs to carry out certain activities. 
This concerns activities related to the circulation of controlled substances; protection of certain particularly important objects of state property, as well as activities related to forensic, legal medicine, forensic psychiatric examinations and the development, testing, production and operation of launch vehicles, including their space launches for any purpose; activities related to the production of gasoline motor mixtures or with the addition (mixing) of bioethanol and/or biocomponents based on it to the hydrocarbon base (gasoline, fractions, components, etc.); activities related to the production of bioethanol (Article 4 of the Law of Ukraine "On Entrepreneurship", 1991).

\section{The mechanism of state regulation of individual's constitutional freedom for entrepreneurial activity in Ukraine}

With the development of commodity production, its monopolization and the complexity of reproduction processes, the possibilities of regulating the market mechanism were limited. The economy is beginning to show significant shortcomings: the imbalance between aggregate supply and demand, inflation, unemployment. All this affects the functioning of business structures. All this affects the functioning of business structures. Not all business entities can adapt to such an economic situation. In these conditions, there is an objective need to intensify the government's role in regulating the economy and the functioning of business entities.

The development of entrepreneurship in Ukraine has reached a stage when the improvement of regulatory policy determines its further prospects. State regulation of entrepreneurship is a system of legal, organizational and regulatory measures of the government aimed at creating a favorable business environment and management of the public sector to ensure the efficiency and competitiveness of the national economy. Ukraine as an independent state today guarantees all entrepreneurs (regardless of their chosen organizational forms of entrepreneurial activity) equal rights and creates equal opportunities for functioning, access to logistical, financial, labor, information, natural and other resources, provided that the work and supplies for public needs. Public administration bodies build their relations with entrepreneurs, using: tax and financialcredit system, which sets tax rates and interest rates on public loans; tax benefits; prices and pricing rules; targeted grants; exchange rate; the size of economic sanctions; state property and the system of reserves, licenses, concessions, leasing, social, economic and other norms and standards; scientific and technical, economic, social, state and regional programs; contracts for the performance of works and supplies for public needs (Buhlak, Zhuravlov, 2016). The government regulates business activities through:
- legislative support of freedom of competition, protection of consumers from manifestations of unfair competition and monopoly in any field of business activity;

- tax, and financial, and credit policy, including the establishment of tax rates and interest rates on government loans, tax benefits, prices and pricing rules, exchange rate, the amount of economic sanctions;

- determination of social norms of enterprise functioning, according to which the entrepreneur is obliged to provide appropriate working conditions, labor safety, wages not lower than the established minimum level, as well as other social guarantees, including social and medical insurance and social security;

- setting ecological norms and standards;

- involvement of entrepreneurs in the implementation of various scientific, technical and economic regional and state programs;

- concluding contracts for the performance of works and providing services for public needs.

The main means of regulatory influence of the state on the activities of economic entities are: government procurement; licensing, patenting and quotas; certification and standardization; application of standards and limits; regulation of prices and tariffs; providing investment, tax and other benefits; providing grants, compensations, targeted innovations and subsidies (Cherednychenko, 2014). Successful development of entrepreneurship is possible only in conditions of ensuring healthy competition, creating a favorable climate and rational support from the government, the effective operation of market mechanisms. Mechanisms of state regulation of entrepreneurship are a system of measures developed by the government, taking into account the market requirements and business entities' interests.

State regulation is carried out through a system of norms and measures governing the business entities' behavior, using both administrative methods of influence (laws, decrees, resolutions, orders, instructions, regulations, etc.) and a system of economic methods and regulators (taxes, prices, bank interest, benefits, sanctions, etc.). State regulation of entrepreneurship has its functions, tools (methods) and relevant bodies. Tools, or methods, of state regulation and support of entrepreneurship can be divided into economic, administrative, and psychological ones. Among the administrative methods, the most important and promising is the regime of the greatest promotion of entrepreneurship with the implementation of the relevant legal framework, which would not interfere with the functioning of large business structures and state enterprises. Economic methods are divided into three groups. Financial methods of business development are: soft loans, availability of investment resources, subsidies, co-financing of socially significant projects. Fiscal methods, a reasonable reduction in the tax burden 
on business structures, which contributes to business expansion, are no less relevant. The resource method is the development of staffing, including training and retraining of labor resources on the basis of government training programs; information support, including participation in exhibitions, conferences, fairs and access of business structures to material resources. Thus, the mechanism of public administration is a complex and systemic formation that organically combines different components: economic, motivational, organizational, political and legal ones (Prokopets, 2018).

The basis of regulatory support are legislative and other regulations, relevant rules of civil, credit and financial, tax, administrative, labor and other fields of current legislation, the main of which is the Commercial Code of Ukraine. The central body that ensures the formation and implementation of state policy in the field of development and support of entrepreneurship is the State Committee of Ukraine for Regulatory Policy and Entrepreneurship. The main task of this body is the formation of business policy, generalization of the practice of application of legislation on business activities, development of proposals aimed at its improvement. In addition, the committee promotes the development of small business, advisory and information support systems and prepares proposals for the introduction and improvement of mechanisms for financial and credit support for entrepreneurship and its foreign economic activity, coordinates the system of training and retraining, etc. In Ukraine, a significant number of public organizations have been established to promote entrepreneurship (Kyrychenko, 2015).

The mechanism of state regulation in Ukraine is enshrined in the Laws "On Protection of Economic Competition", "On Protection against Unfair Competition", "On Advertising”, "On Audit”, in the Tax Code of Ukraine, the Commercial Code of Ukraine. Regulation of foreign economic activity of business structures is carried out on the basis of the provisions set out in the Law of Ukraine "On Foreign Economic Activity”, which are fundamental for all business entities and should be taken into account in the organization of this activity.

It is necessary to focus on the means of technical regulation, consisting of norms, standards, limits and standardization system, aimed at economic entities' activities to "achieve the optimal degree of regulation in a particular area, resulting in increased compliance of products, processes and services their functional purpose, elimination of barriers to trade and promotion of scientific and technical cooperation" (Krehul, Bank, 2016). We can state that the main principles of state support for entrepreneurship are organizational structures for staffing and scientific and methodological support, as well as a developed market infrastructure and information and consulting support for entrepreneurship.
Considering the experience of state regulation of entrepreneurship in the EU countries, it is important to emphasize that the concept of supporting small and medium-sized businesses is clear and understandable. It takes into account national and European interests, includes the goals and principles of such a policy, mechanisms and organizational structures for its implementation. Today, the share of small businesses, which is constantly growing in the UK economy, accounts for $25 \%$ of the total workforce. Italy is recognized to be a European leader in this field with almost 800,000 industrial enterprises in the country and a share of $99 \%$ of small and medium-sized enterprises in total. In Germany and the Netherlands, small and medium-sized businesses provide about $40 \%$ of exports, in Italy - 25-30\%, in France - 20-25\%, in Japan $-10-15 \%$. The main areas of state support for small and medium enterprises in the EU are the formation of infrastructure to support and develop entrepreneurship, the establishment of a system of benefits and a transparent tax system, the availability of financial and credit support and cooperation with large enterprises and more. However, this does not mean the creation of "greenhouse" conditions for small and medium enterprises, but rather is a means of equalizing the opportunities of small, medium and large enterprises in a competitive environment, a way to compensate entrepreneurs for activities in risky areas. In the United States, despite the spread of the idea of maximizing freedom of economic activity, the role of the state in regulating business is important, although ambiguous. Relations between it and the business sector have a "wave-like" tendency - from regulating business to deregulation (i.e. reducing government impact on business), which spread in the late 1960s and became widespread in the 1970-80s. Most American scholars note that at the present stage, the relationship between business and the state is antagonistic, and the partnership between them is considered to be impossible and harmful to society. At the same time, although business entities make most of their decisions on their own, their area of activity is shrinking and, accordingly, the area of state influence is increasing. This tendency to increase the government's participation in the regulation of entrepreneurship is becoming widespread and, as analysts emphasize, has an upward trajectory.

As for Ukraine we can note that the priority of state regulation and support of small and medium enterprises in the information society necessitates the transition from direct administrative assistance to the formation of a favorable economic and social environment to improve mechanisms and tools to promote small and medium enterprises. According to foreign experience, the most flexible and favorable for the implementation of scientific, technical and innovative achievements are small businesses. However, their share in the creation 
of GDP in Ukraine is much smaller than in countries with developed market economies. The state can help solve this problem by: directing part of the funds received from the privatization of state property to the development of the material and technical base of entrepreneurship; development and implementation of a mechanism for the transfer for small businesses of surfaces and production facilities, including those that are vacated in the process of liquidation, reorganization and bankruptcy of enterprises; use of production potential of enterprises on leasing terms, which will allow business structures to minimize the cost of acquisition of fixed capital, and the ability to contribute a share of property to their founding capital or transfer it to the economic management of business structures will increase their collateral capacity and stability; promoting the process of forming a developed real estate market.

\section{Anti-offenses in business as a guarantee of individual's constitutional freedom to conduct business in Ukraine}

Analyzing the system of anti-offenses actors, we should note that they form a holistic functional and organizational mechanism, which is characterized by a common goal and management in the field of anti-offenses. The specificity of this mechanism is due, on the one hand, to the multiplicity of functions performed to ensure security, prevention, termination, consideration, investigation and detection of offenses, and on the other hand, to the distribution of tasks between actors at different levels, due to hierarchical system. This system is a complex social organization, because its constituent groups of homogeneous bodies form relatively independent organizational formations that operate on the basis of identical patterns. Each of these formations is a subsystem of a larger system and the same time consists of its own subsystems (Khomko, Kulhavets, 2016).

In addition, we propose to include public administration bodies, judicial bodies, and the whole complex of enterprises, institutions and organizations operating in various areas of social life, etc., as antioffenses actors. However, it is necessary to pay attention to an important feature of this activity. This range of functions is performed by the vast majority of these bodies in conjunction with the solution and implementation of other tasks. Only for a relatively small number of such entities the crime prevention function is the main activity. These bodies are endowed with appropriate rights and responsibilities to impact certain criminogenic factors; in this regard, they provide appropriate information, methodological, logistic support and staffing.

Let us note that some scholars include to the crime prevention actors: the actors who directly make individual prevention; actors making prevention exercising their control and law enforcement functions; actors primarily engaged in the management and coordination of offenses prevention activities; and even the Orthodox Church (Bachynskyi, 2018). However, in our opinion, given the specifics of the subject under study, such provisions are quite controversial.

We also agree with the position of those researchers who include the President of Ukraine and the Cabinet of Ministers of Ukraine to the actors that determine the directions and tasks of anti-offense, which "form the legislative and other regulatory bases of anti-offense, establish competence, rights and responsibilities of other actors of this activity, carry out its financial, staff, logistical and other resource support, planning, control and other functions of state and legal management in this area", to the subjects carrying out information and analytical support of anti-offense - relevant units of the National Police, the Security Service of Ukraine, prosecutor's offices and other law enforcement agencies; to the actors revealing criminogenic factors - units of law enforcement system. The last group contains the entities that implement measures to respond to some offenses and crime in general.

Summarizing the above, we can specify the anti-offense actors as follows: public authorities and administration; local self-governments; executive and administrative bodies; National Police of Ukraine; Security Service of Ukraine; prosecutor's office; courts; general and economic management bodies; information, statistical, medical, educational and cultural-educational bodies; trade unions, community policing agencies, parties, religious organizations; juvenile services; correctional institutions etc. Based on this anti-offense actors list, it is possible to determine the system of their powers. In generalized form, these bodies exercise the following anti-offense tasks and functions:

- draw up main directions, tasks, forms and methods of combating crime in the country;

- provide information and analytical support for combating offenses;

- identify criminogenic factors and signal about them;

- directly implement measures to respond to certain offenses, as well as measures to eliminate, reduce or neutralize criminogenic factors, including measures to correct personal deformities and eliminate the circumstances that formed them (Kasianenko, 2018).

Analyzing the concept and essence of the offense prevention actors, we can state that the range of their powers in this area (except for special bodies) is quite wide and common to many areas of social life of the state and society, and entrepreneurship is no exception. Thus, we propose to consider the anti-offenses actors in business as a system of state and non-governmental bodies, public organizations, social groups and citizens, whose activities are aimed at eliminating the causes and conditions that give rise to and contribute to business 
offenses, preventing the commission of these offenses at various stages of participants' illegal behavior in relations in the field of entrepreneurship, as well as to bring them to justice.

We should note that the range of anti-offense actors in business is very wide, so to analyze the activities of all within our study is not possible (Bilousov, 2017). As we have already mentioned, for most of these actors, combating offenses is a task that is performed together with the main tasks, such as forming the legal framework and identifying initiatives in this area, management, control and supervision of legal entities in the field of economic activity in general and business entities in particular, as well as their compliance with relevant legislation. Relevant bodies specially established for this purpose, including non-governmental ones, are empowered directly to combat offenses in business activities.

In addition, according to the Commercial Code of Ukraine, measures to control business activities are carried out by state supervision bodies for compliance with nuclear and radiation safety requirements (except for state supervision of activities with ionizing radiation sources, the use of which is not subject to licensing), state architectural and construction control (supervision), state supervision in the field of economic activity for the provision of financial services (except for the transfer of funds, financial services in the securities market, derivative securities (derivatives) and the banking services market), state supervision and control over compliance with labor legislation and employment of the population in the manner prescribed by law, taking into account the features defined by law in relevant areas and international treaties, including state supervision (control) in the field of civil aviation - taking into account the features established by the Air Code of Ukraine, regulations, adopted for its implementation (Aviation Rules of Ukraine), and international agreements in the field of civil aviation.

Thus, the system of anti-offense actors in business is rather numerous and various, therefore depending on such criteria as a form of ownership, nature of activity, a complex of powers in the field under study, we suggest to divide the specified bodies into several groups:

1. Public authorities of general competence exercising anti-offense powers in business along with their main functions (the Verkhovna Rada of Ukraine and local self-governments; President of Ukraine and the Presidential Office; Cabinet of Ministers of Ukraine and local state administrations; Ministry of Finance of Ukraine; Ministry for Development of Economic, Trade and Agriculture of Ukraine, State Fiscal Service of Ukraine, law enforcement agencies (Security Service of Ukraine, Ministry of Internal Affairs of Ukraine, National Police of Ukraine, Prosecutor's Office, etc.), judicial authorities, other central executive bodies engaged in combating business offenses along with its main functions).

2. State specialized committees, departments, services and inspections established directly to combat business offenses (State Fiscal Service of Ukraine; State Financial Inspection of Ukraine; Department of Strategic Investigations of the National Police of Ukraine; Antimonopoly Committee of Ukraine; State Service of Ukraine for Food Safety and Consumer Protection); State Property Fund of Ukraine; State Treasury Service of Ukraine, etc.).

3. Bodies of the financial and credit system (National Bank of Ukraine; commercial banks).

4. Non-governmental anti-offenses actors in business.

It should be noted that some of these public authorities (administrative commissions, district, district in cities, city or city-district courts, the National Police of Ukraine, state financial control bodies, bodies of revenues and duties, etc.) can be allocated to a special group of entities endowed with administrative and jurisdictional powers. An exhaustive list of them is contained in Section III "Bodies authorized to consider cases of administrative offenses" of the Code of Ukraine on Administrative Offenses. These actors have the right to consider cases of administrative offenses, the components of which are listed in Chapter 12 "Administrative offenses in trade, catering, services, finance and business" of the Code of Ukraine on Administrative Offenses (1984), and authorized to bring perpetrators to administrative liability.

\section{Conclusions}

The individual's constitutional freedom to conduct business is an economic opportunity of a person for independent, initiative, systematic, activity at individual's own risk to exercise the right to manufacture products, perform works, provide services, engage in trade for profit according to the Constitution and not prohibited and detailed by the laws of Ukraine. Attributes of the individual's constitutional freedom to entrepreneurial activity are: enshrining it in the Constitution and laws of Ukraine; no restriction or prohibition of human opportunities for entrepreneurial activity; independence, initiative, systematicity, riskiness of activity; production, performance of works, providing of services, doing trade; profit.

We propose to amend the legislation as follows: a) Art. 42 para. 1 of the Constitution of Ukraine before the words "Everyone has the right to entrepreneurial activity"... (The Constitution of Ukraine) to insert words "Freedom of entrepreneurship in Ukraine is guaranteed" and further in the text; b) Art. 43 of the Commercial Code of Ukraine instead of the words "entrepreneurs have the right" to enshrine "entrepreneurs are guaranteed freedom" and further in the text. The implementation of the proposed 
conclusions and recommendations will help to improve the realization of the individual's constitutional freedom to conduct business.

Today, business activity requires detailed legislative regulation, which is intended to promote the further development of various forms of entrepreneurship and the economy of Ukraine as a whole. Nowardays there is no special regulation that would establish the legal status of a citizen-entrepreneur, and objective prohibitions and restrictions on doing business, so it is necessary to adopt a new regulation which would have secured the appropriate status and management features individual entrepreneur as a business entity. It would be advisable to establish a list of activities in which entrepreneurship is prohibited, in Art. 128 of the Commercial Code of Ukraine.

\section{References:}

Vinnyk, O. M. (2017). Business Law: a course of lectures (general part). Kyiv: Lira-K, 239 p.

Commercial Code of Ukraine: Law of Ukraine: Law of Ukraine No. 436-IV dated January 16, 2003. Available at: https://zakon.rada.gov.ua/go/436-15

On Farming: Law of Ukraine No. 973-IV dated June 19, 2003. Available at: https://zakon.rada.gov.ua/go/973-15

The Constitution of Ukraine No. 254к / 96-BP dated June 28, 1996. Available at: http://www.zakon.rada.gov.ua/ go/254к/96-вp

On Entrepreneurship: Law of Ukraine No.698-XII dated February7, 1991. Available at: https://zakon.rada.gov.ua/ go/698-12

Buhlak, Yu. O., \& Zhuravlov, D. V. (2016). Administrative and legal principles of de-shadowing of relations in business: a monograph. Kyiv: Helvetica, 199 p.

Cherednichenko, H. A. (2014). The mechanism of state regulation of business activity in Ukraine and directions of its improvement. Economics and management: problems of science and practice: Collection of scientific articles. Nuremberg: Verlag SWG imex GmbH, vol. 1, pp. 162-167. Available at: http://conf.at.ua/archive/19_12_2014_ Vol_1.pdf

Prokopets, L. V. (2018). Mechanisms of state regulation of entrepreneurial activity. Business navigator, vol. 1-1, pp. 162-166.

Kyrychenko, Yu. V. (2015). Constitutional regulation of the right to entrepreneurial activity in Ukraine and the countries of continental Europe. Scientific Bulletin of Kherson State University. Series: Legal Sciences, vol. 5(1), pp. 75-79.

Krehul, Yu. I., \& Bank, R. O. (2016). Security of entrepreneurial activity in Ukraine: administrative and legal aspect: monograph. Kyiv: Kyiv National University of Economy and Trade, 239 p.

Khomko, L. V., \& Kulhavets, Kh. Yu. (2016). Legal regulation of entrepreneurial activity: a textbook. Lviv: Lviv Department of Internal Affairs, 423 p.

Bachynskyi, A. Ya. (2018). Mechanisms of state regulation of business activity in Ukraine. Scientific notes of Taurida National V.I. Vernadsky University. Series: Public Administration, vol. 29(68), issue 2, pp. 52-55.

Kasianenko, D. I. (2018). Peculiarities of managing an individual as a business entity. Young scientist, issue 10(2), pp. 659-662.

Bilousov, Ye. M. (2017). Actual problems of economic and legal support of economic security of Ukraine: monograph. Kharkiv: Pravo, 239 p.

Code of Ukraine on Administrative Offenses: Law of Ukraine No. 8073-X dated December 7, 1984. Available at: http://www.zakon.rada.gov.ua/go/80731-10 